\title{
Kreativitas Garap sebagai Strategi Pengembangan Musik Kompang Grup Delima di Bantan Tua Bengkalis
}

\author{
Rosta Minawati, Nursyirwan \\ Program Studi Televisi dan Film dan Program Studi Seni Musik, \\ Fakultas Seni Rupa dan Desain dan Fakultas Seni Pertunjukan \\ Institut Seni Indonesia Padangpanjang \\ Jalan Bahder Johan Padangpanjang, Padangpanjang Timur 27128 \\ Email: rostaminawati@yahoo.co.id; doctornursyirwanmsn.ugm2011@gmail.com
}

\begin{abstract}
This article aims to discover the strategy of creativity used by performers of Kompang music in Bantan Tua, Bengkalis. The data was collected through observation, interviews, and documentation. The Kompang Delima Group is one of the kompang groups that has developed kompang as performing art. In 2012 the Delima Group started to include creative movements in their performances. The movement creativities were inspired by the social and cultural life of the people. Nunduk is one of the characteristic movements of the Delima Group in Bantan inspired by menoreh (harvesting a rubber). The creativities are developed through the elements of local culture, including movements, formations, and floor patterns, and the emphasis on the clarity of articulation in each line of the recitation of the barzanzi text in order to gain more aesthetic impression of performance.
\end{abstract}

Keywords: creativity, Kompang music, Delima group, Bengkalis

\begin{abstract}
ABSTRAK
Tulisan ini bertujuan mengungkap strategi kreativitas pemain musik Kompang di Bantan Tua Bengkalis. Data dikumpulkan melalui observasi, wawancara, dan dokumentasi. Grup Kompang Delima adalah salah satu grup Kompang yang mengembangkan musik Kompang sebagai seni pertunjukan. Pada tahun 2012, Grup Delima mulai memasukkan gerak yang kreatif di dalam pertunjukannya. Hasil kreativitas yang dilakukan dengan menggarap gerak yang terinspirasi dari kehidupan sosial dan kultur masyarakatnya. Nun$d u k$ adalah gerakan yang khas yang dimiliki grup Delima di Bantan Tua yang terinspirasi dari menoreh (mengambil karet). Kreativitas dilakukan dengan mengembangkan gerak, formasi dan pola lantai, serta penekanan pada kejelasan artikulasi setiap syair barzanji yang dilafalkan agar tercapai kesan estetik dalam penampilannya.
\end{abstract}

Kata kunci: kreativitas, musik Kompang, grup Delima, Bengkalis 


\section{PENDAHULUAN}

Era globalisasi ditandai dengan kemajuan pengetahuan, teknologi, dan media. Keberadaan kebudayaan bukan hanya sebagai konsep ide saja yang tertuang atau dikonsumsi oleh masyarakat pendukungnya, akan tetapi telah dijadikan sebagai modal yang harus dikelola, diciptakan, dan menjadikannya sumber kesejahteraan baru bagi masyarakatnya. Berkaitan dengan itu Ratna menyatakan bahwa lokal tidak harus diartikan sebagai sesuatu yang sederhana, rendah, sempit, karena kebijaksanaan lokal yang memuat pengetahuan lokal mencerminkan kebudayaan setempat sebagai sesuatu yang pernah dipinggirkan atau dimarginalkan (2011: 90).

Di Bengkalis, hidup dan berkembang seni pertunjukan yang bernafaskan Islam, yakni pertunjukan Kompang. Konteks pertunjukan Kompang dapat ditemui di setiap perayaan hari-hari besar Islam, seperti maulid Nabi Muhammad SAW, Hari Raya Idul Fitri, penyambutan Ramadhan, khataman Al Qur'an, akikah, khitanan, perayaan 1 Muharam, perkawinan, menyambut tamu pemerintahan dan MTQ. Menurut Hadi (2012: 1-2), seni pertunjukan bertujuan mempertunjukkan atau menyajikan sebuah karya seni pertunjukan kepada masyarakat.

Kompang adalah sejenis alat musik pukul menyerupai rebana, terbuat dari kulit kambing dan kayu leban, yang dilengkapi dengan sedak (penyaring suara). Syair-syair yang dinyanyikan pada saat pertunjukan musik Kompang bersumber dari kitab barjanzi. Barzanji merupakan karya sastra arab yang ditulis oleh Syech Albarjanzi berisi cerita bernafaskan Islam berupa puji-pujian kepada Allah SWT dan Nabi Muhammad SAW beserta keluarganya (Minawati dan Nursyirwan, 2015: 133).

Di Bantan Bengkalis terdapat pertunjukan Kompang menampilkan atraksi-atraksi gerak dalam pertunjukannya dengan energik dan kreatif. Daya tarik dalam pertunjukan ini terletak pada gerakan-gerakan memainkan kompang dengan diiringi nyanyian dan pukulan-pukulan kompang secara rampak dan teratur. Gerak tersebut merupakan salah satu kreativitas dalam melestarikan dan mengembangkan seni tradisi tanpa meninggalkan nilai-nilai dari ketradisiannya. Dalam kaitan ini, Murgiyanto (2004: 3) menyatakan bahwa kelangsungan sebuah tradisi sangat bergantung pada kreativitas atau inovasi yang terus menerus dari pendukungnya dalam mengembangkan keunikan individual, detail, kebiasaan, persepsi internal, dan eksternal.

\section{METODE}

Penelitian ini adalah penelitian kualitatif. Penelitian kualitatif digunakan berdasarkan pada beberapa pertimbangan. Pertama, penelitian kualitatif lebih mudah apabila berhadapan dengan kenyataan ganda. Kedua, penelitian kualitatif menyajikan secara langsung hakikat hubungan antara peneliti dengan informan, dan ketiga, penelitian kualitatif lebih peka dan lebih menyesuaikan diri dengan pengaruh atas pola-pola nilai yang dihadapi (Moleong, 1999: 5). Metode penelitian merupakan serangkaian tahapan atau langkah-langkah yang secara sistematis dilakukan dalam melaksanakan penelitian.

Brannen (2005: 11) menyatakan penelitian dengan cara kualitatif sesuai dengan pendefenisian konsep-konsep yang sangat umum dengan cara observasi partisipatoris (peneliti ikut terlibat dalam penelitian). Keterlibatan peneliti secara langsung dalam penelitian adalah jembatan dalam mencapai penafsiran data-data yang didapat untuk mencapai kesimpulan dalam menjawab permasalahan pada topik yang diajukan.

Penelitian ini menggunakan metode deskriptif analisis. Menurut Sedyawati, deskriptif dilakukan agar mendapatkan gambaran terhadap pokok permasalahan, dan analisis dilakukan untuk memuncul- 
kan fakta-fakta yang dapat memberikan pandangan yang lebih mendalam dan menyeluruh mengenai permasalahan yang akan dibahas (2004: 2).

Sumber data dalam penelitian ini dibagi dalam dua kategori, yakni sumber data tertulis dan sumber data lisan. Sumber data tertulis berupa sumber tercetak dan sumber data tertulis dalam bentuk manuskrip. Sumber tertulis yang tercetak dapat berupa buku, jurnal, ensiklopedi, kamus, brosur, surat kabar, dan surat-surat berharga lainnya, arsip, serta dokumen (Soedarsono, 2001: 128). Soedarsono juga mengatakan bahwa sumber data secara primer memberi peluang kepada peneliti untuk menginterpretasikan dengan interpretasinya sendiri, bukan hanya meminjam interpretasi peneliti lain, dalam menguak misteri yang terekam di dalamnya. Data yang dikumpulkan melalui studi pustaka, observasi, wawancara, dan dokumentasi dikelompokkan dan di analisis sesuai dengan tujuan penelitian.

\section{HASIL DAN PEMBAHASAN}

\section{Kreatif Meraih Peluang: Budaya Lokal sebagai Kekuatan}

Eksistensi pertunjukan musik Kompang di Bantan Tua berkontribusi pada keberlangsungan dan stabilitas budaya masyarakatnya. Fungsi seni dalam kesenaian ini memiliki beberapa fungsi. Pertama, sebagai hiburan pribadi, yakni untuk kepuasan pribadi, baik sebagai pemain, pengelola, maupun sebagai anggota masyarakat pendukung budaya (seni Kompang). Kedua, sebagai hiburan kelompok dalam membawakan repertoar yang dimainkan dengan sederhana dan keterbatasan, baik alat, pengetahuan manajemen, dana oprasional, dan lain lain. Di Bantan Tua, hal menarik pada kelompok Delima bahwa seluruh anggota kelompok memiliki hubungan keluarga (mertua, kakak beradik, beripar, atau keponakan). Ketiga, sebagai hiburan masyarakat, yakni dalam bentuk pertun-

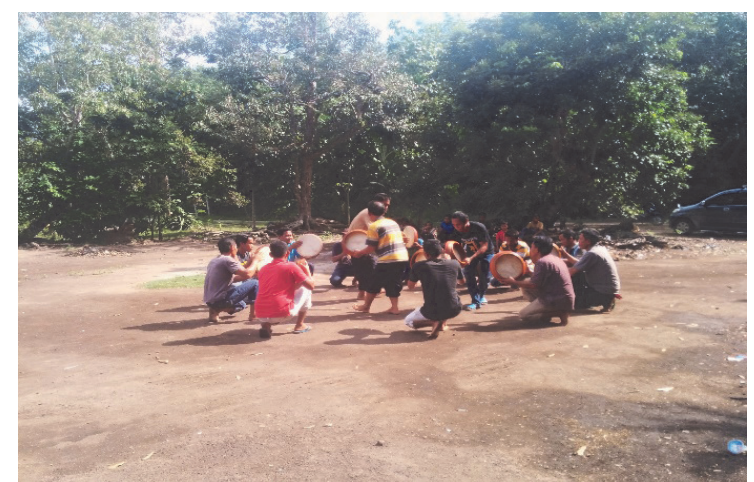

Gambar 1. Latihan formasi gerak melingkar pada sore hari

Dok. Rosta Minawati dan Nursyirwan, 2016

jukan (hiburan) dalam berbagai kegiatan sosial budaya masyarakat, misalnya hajat perkawinan, sunatan, acara keagamaan, dan acara pemerintahan.

Konsep penggarapan dengan menghadirkan kreativitas pada pertunjukan Kompang menekankan pada pengolahan pola lantai dan gerak atraksi. Sedangkan pada arasemen musik tidak dilakukan perubahan, yakni tetap merujuk pada 12 (dua belas) motif pukulan. Walaupun demikian, permainan musik Kompang tetap unik dan menarik, dan memiliki variasi dan keragaman. Hal tersebut oleh karena musik Kompang merupakan seni tradisonal yang memiliki celah ruang ketidakmapanan dan konsistensi. Hal ini terutama disebabkan oleh hadirnya ekspresi dari setiap pemain. Pola penyajian masih memiliki kemapanan terutama dalam melakukan pukulan dan urutan pelafalan syair-syair yang disebut hadi (tanya-jawab).

Kegiatan tersebut terlihat sederhana, akrab, dan dinamis sehingga siapapun dapat hadir dan menjadi pemain dalam pertunjukan Kompang di Bantan Tua. Kebiasaan latihan dilakukan pada malam hari setelah sholat Magrib atau Isya, terkadang dilakukan juga pada pagi atau siang hari jika mendapat panggilan pertunjukan atau berlatih untuk mengikuti even pertunjukan. Proses latihan grup Kompang Delima Bantan Tua dapat dilihat pada gambar 1. 
Proses latihan yang dilakukan sesuai dengan kebutuhan dan kesempatan. Manajemen latihan masih belum terkelola dengan baik. Hal tersebut oleh karena manajemen yang dilakukan masih bersifat tradisional atau bersifat kekeluargaan sebagaimana terjadi pada proses pembentukannya. Hal yang sama dapt ditemui dalam kasus kesenian lain, seperti dalam tulisan Widjajadi (2000: 12) mengenai kelompok orkes keroncong yang masih amatir kendati ada pula yang mengarah ke sistem profesional. Dalam sistem ini, tidak terdapat kesepakatan secara tertulis tetapi lebih sering didasari atas kesepakatan dan jiwa kegotongroyongan atau guyub. Penyandang dana latihan ditanggung oleh anggota dengan makanan dan minum yang sederhana. Situasi seperti ini dapat ditemukan di perkampungan. Menurut Widjajadi (2000: 6), setiap genre musik memiliki komunitas tersendiri. Kondisi tersebut tidak terlepas dari perkembangan dan perubahan fungsi maupun bentuk, terutama pola penyajiannya. Hal tersebut oleh karena pertunjukan mengalami perubahan dan perkembangan masyarakat penikmatnya.

Kemauan politik masyarakat dan pemerintah telah menempatkan peran kebudayaan dan musik Kompang sebagai ikon budaya di Bengkalis. Hal itu terlihat dengan semakin banyaknya kelompok-kelompok Kompang di desa-desa, kecamatan, dan kabupaten di Bengkalis. Pemerintah turut melakukan usaha dalam membina, mengembangkan dan melestarikan budaya musik Kompang yang dilakukan perorangan, kelompok, dan masyarakat, baik secara formal maupun non formal.

Kegiatan-kegiatan berkesinambungan dalam pengembangan kebudayaan merupakan perwujudan berbagai pertunjukan musik Kompang. Keterkaitan estetika dan etika dalam pertunjukan musik Kompang tidak terlepas dari syair yang disampaikan, gerakan tubuh, pukulan-pukulan
Kompang, dan tata busana. Keterbukaan idiom-idiom pertunjukan musik Kompang berhubungan dengan kreativitas dan inovasi. Momentum seperti ini dilakukan dalam seni tradisi sebagai bentuk revitalisasi dan pelestarian budaya. Sebagaimana yang dikatakan To Ngoc Thanh "kebudayaan tradisional harus dikembangkan untuk memiliki wajah baru dan bukan hanya menyesuaikan diri saja tetapi dapat berkembang dalam kondisi masyarakat sekarang" (Bramantyo, 2000: 108). Pendapat tersebut juga didukung Bramantyo bahwa:

Seni tradisi bukanlah benda mati, seni tradisi secara kronologis selalu berubah untuk mencapai tahap mantap menurut tata hidup pada zamannya. Dengan demikian, seniman dituntut untuk selalu pandai menyesuaikan diri. Pelestraian seni tradisi tidak mempunyai keharusan untuk mempertahannkan seperti semula. Perubahan sebagai arahan tidak berarti merombak, melainkan membenahi salah satu atau beberapa bagian yang dirasa tidak memenuhi selera masa kini (Bramantyo, 2000: 109).

Dengan demikian, kreativitas dan inovasi dengan mengeksplorasi pertunjukan Kompang Bantan Tua dalam grup Delima turut memperkaya khazanah seni budaya. Karena 'kalau seniman tradisi hanya memainkan saja' seni yang telah ada sama dengan mematikan kreativitas dan daya hidup pertunjukan musik Kompang sebagai seni tradisional.

Di Bantan Tua Bengkalis, untuk mempertahankan dan mengembangkan kehidupan musik Kompang dibutuhkan kreativitas pada kesenian tersebut. Istilah perkembangan menurut Sedyawati memberikan kesan kuantitatif, yakni membesarkan dan meluaskan. Artinya, memperbanyak frekuensi penyajian pementasan dan memperluas wawasan apresiasi (Kasidi, 2000: 142). Perubahan pola pikir masyarakat, kelompok, dan pemain musik Kompang turut mengubah dan memudarkan sistem nilai yang dipegang teguh dalam kelangsungan pertumbuhan musik Kompang. 
Seperti dalam kreativitas Mang Koko, menurut Ruswandi (2016: 105), ia membuat karya atas dorongan dari dalam dirinya sendiri untuk mengekspresikan rasa estetisnya, membuat karya baru dengan merespon situasi lingkungan, memberi warna pada vokal, memperkaya musik pengiring dan mendidik generasi penerus (anak-anak sekolah). Hal tersebut hampir sama dengan praktik kreativitas yang dilakukan kelompok Kompang Delima Bengkalis. Hasil kreativitas yang dilakukan, yakni dengan menghadirkan gerak pada pertunjukan musiknya. Gerakan-gerakan yang dilakukan terinspirasi dari kehidupan sehari-hari menorah, yakni kegiatan mengambil karet. Gerakan khas dalam kelompok tersebut disebut dengan nunduk. Kreativitas dilakukan pada formasi pola lantai sebagai garis yang dilalui dalam pertunjukan, dengan memberi ketegasan dalam pelantunan artikulasi syair barjanzi. Hal ini merupakan kreativitas atas pewarisan pada anak-anak mereka dengan cara mereka sendiri dengan melatih musik Kompang dan membentuk kelompok kompak anak. Menurut Didi Supriadi, kreativitas merupakan kemampuan seseorang dalam melahirkan sesuatu yang baru baik berupa gagasan maupun karya nyata yang relatif berbeda dengan apa yang telah ada sebelumnya (Ruswandi, 2016: 92). Sehubungan dengan itu, Sumardjo menyatakan bahwa proses kreativitas seniman tidak dapat dimungkiri dipengaruhi oleh lingkungan kultur sosial masyarakatnya (Wikandia, 2016: 58).

Berpikir kreatif merupakan suatu strategi dalam pengembangan budaya lokal. Budaya lokal yang memuat kearifan lokal sering dipahami sebagai kearifan lokal. Dalam hal ini, Ratna menyatakan bahwa kearifan lokal sering dikacaukan dengan pemahaman lain, sebagai kebudayaan lokal (local culture) (2011: 91). 'Lokal' secara spesifik menunjuk pada ruang interaksi terbatas dengan sistem nilai yang terbatas pula.
Merangsang ide kreatif sebagai strategi pengembangan budaya lokal tentu saja tidak lepas dari persoalan industri kreatif. Secara sederhana, industri kreatif dapat dipahami untuk menciptakan ranah industri yang didasarkan atas daya kreativitas yang tinggi untuk menghasilkan produk baru yang berbeda dan berkualitas. Produk diciptakan melalui ide, gagasan-gagasan dengan menghasilkan suatu nilai lebih melalui karya yang dihasilkan, dengan tingkat efektivitas dan efisiensi yang tinggi. Pertunjukan Kompang dengan tampilan unik dapat diterima konsumen untuk mendorong peningkatan pendapatan dan perputaran ekonomi bagi pemainnya. Ragam gerak hasil kreativitas gerak oleh Grup Kompang Delima Bantan Tua.

Sesungguhnya, kreativitas adalah proses mental dan sosial yang selain melibatkan penemuan ide-ide atau baru konsep juga memiliki dampak terhadap lingkungan masyarakat. Kreativitas yang memiliki nilai, bisa berbentuk solusi baru untuk suatu masalah, metode baru atau perangkat, atau obyek artistik baru, bentuk atau ide lainnya. Untuk praktek kreativitas, seseorang dituntut kaya dengan ide, kreativitas, ketanggapan, dan kritis dalam menyikapi domain tertentu dan mengeksplorasi peluang dan kesempatan untuk melangkah keluar dari kotak keterkungkungan yang menjenuhkan (mati). Kreativitas sebagai proses berpikir digunakan untuk menghasilkan pemikiran berbeda yang bertujuan untuk menghasilkan ide-ide berbeda dan bermanfaat bagi diri serta orang lain. Menurut Julianto, dkk., (2016: 25) fenomena perubahan kebudayaan merupakan akibat proses pergeseran, pengurangan, dan penambahan unsur sebuah sistem karena ada proses interaksi manusia dengan lingkungan sosialnya.

Secara umum, menurut Ratna kearifan lokal memiliki ciri-ciri universal dalam arti gejala tersebut hadir dari berbagai komuni- 
tas atau kelompok masyarakat, meskipun disampaikan dengan bahasa yang berbeda (2011: 92). Penggalian dan pemanfaatan budaya lokal menjadi sebuah produk budaya sebagai strategi pengembangan budaya lokal dalam pengertian industri kreatif, di antaranya dapat dilakukan melalui ide kreatif yang inspiratif, inovatif, dan imajinatif. Sebagaimana pendapat Soegoto bahwa berpikir kreatif akan dapat meraih peluang untuk membuka lapangan kerja, mengurangi pengangguran, dan membuat perekonomian warga terus tumbuh (2009: 39). Kreativitas formasi gerak yang dilakukan oleh pemain Kompang dalam pertunjukan musik Kompang dapat dilihat pada gambar 2.

Keseluruhan gerak dan formasi pola lantai dilatih oleh kelompok Kompang Bengkalis Riau. Pada proses tersebut terdapat kreativitas yang melahirkan kreasikreasi baru, dengan perkembangan yang disesuaikan dengan konsep pertunjukan. Di dalam konsep pertunjukan tersebut telah memperhitungkan konsep-konsep estetika yang memberikan nilai-nilai keindahan atas dasar suguhan yang diatraksikan oleh para pemain Kompang. Menurut Ahmad, nilai-nilai keindahan itu terletak pada ketepatan pukul, lagu, dan gerak (Wawancara 15 Oktober 2016).

\section{Strategi Kreatif dalam Pengembangan Kesenian Kompang}

Strategi kebudayaan mengandung pengertian cara atau usaha merencanakan dapat diwujudkan. Tylor menegaskan bahwa kebudayaan merupakan suatu hasil karya manusia (Poespowardojo, 1987: 219). Hal tersebut berarti kebudayaan adalah sebuah bentuk ungkapan manusia yang dilakukan secara bertingkat, berproses dalam ruang dan waktu sehingga kebudayaan tidak pernah mati (statis), akan tetapi terus hidup (berkembang) mengikuti perkembangan pengetahuan dan kreativitas masyarakatnya.

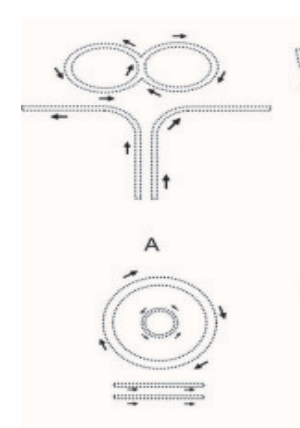

D

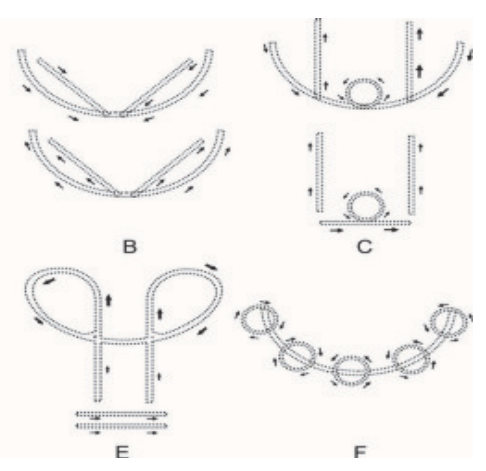

Gambar 2. Skema Pola lantai pertunjukan Kompang Delima Sumber: Hidayat Sidik, 2015
Alatas menyatakan bentuk ide kreatif lain sebagai strategi adalah semangat berfikir dan berfalsafah, ingin mengetahui sebab-sebab dari suatu persoalan, menghormati cara-cara ilmiah, menggunakan akal seluas-luasnya, sadar akan ketergantungan hubungan antara kejadian, persoalan, usaha ataupun alam, memiliki pedoman yang jelas dan maju, melihat persoalan dari segi keseluruhan, dan tidak putus asa dalam menghadapi persoalan (1976: 338).

Oleh karena itu, sangat beralasan jika kearifan lokal merupakan entitas yang sangat menentukan harkat dan martabat manusia dalam komunitasnya. Sebagaimana dikatakan Poespowardojo (1987: 236-237), kebudayaan bukan hasil dari beberapa individu, akan tetapi mengikutkan keterlibatan beberapa generasi untuk menjamin kelangsungan budaya tersebut. Hal tersebut merupakan sebuah strategi kebudayaan.

Segala aktivitas dan kreativitas masyarakat Bantan Tua bersandar pada nilai dan norma budaya yang juga merujuk kepada syariat agama (Islam). Artinya, semodern apa pun pola pikir dan pola tindak laku individu dalam upaya memenuhi kebutuhan hidup, tetap harus bersandar kepada adat dan syariat agama (Islam). Begitu pula dengan aktivitas dan kreativitas musik Kompang sebagai upaya pemenuhan kebutuhan jasmani dan rohani manusia, baik sebagai hiburan maupun kegitan sosial lainnya. 
Pada kenyataannya, kreativitas itu bermacam-macam bentuknya sesuai kondisi sosial budaya masyarakat setempat. Perbedaan seni tradisi di berbagai wilayah menurut Raharja, yakni (1) berdasarkan struktur, (2) musiknya, (3) instrumenya, (4) fungsi sosialnya latar belakang sejarahnya, dan berdasarkan praktik musikalnya (2000: 13).

Di sini, persoalan fenomena estetik dapat dikritisi dari sisi objek, kualitas, pengalaman dan nilai. Dalam pandangan ini, Barker menyatakan bahwa persoalan penilaian kualitas estetis diturunkan dari suatu hirarki selera kultural berbasis kelas yang terlembagakan (1984: 55). Musik Kompang sebagai kesenian tradisional telah terpatri kuat dalam benak masyarakatnya, baik penonton, seniman, budayawan sebagai artefak budaya. Kesenian Kompang sebagai intisari dari budaya Melayu Riau itu terekspresikan dari pertunjukannya.

Ide-ide spontanitas dan improvisasi dalam berkesenian, bukanlah hal yang baru, namun tetap memiliki batasan-batasan (pakem) dari budaya pendukung kesenian tersebut. Menurut Barker, faktor runtuh atau tenggelamnya sebuah kebudayaan adalah karena persoalan struktur sosio-ekonomis dan politis yang di dalamnya terdapat faktor mental, mandulnya daya cipta, pudarnya jiwa inovatif (1984: 78-79). Terjadinya pergeseran nilai estetik mengharuskan kita untuk berpikir kreatif dengan berbagai pengembangan, baik bersifat inovasi (kebaruan) dalam bentuk revitalisasi atau silang budaya. Dalam hal ini, Sachari berpendapat bahwa kertikatan pakem pada nilai estetik tradisional dalam kurun waktu mengalami perubahan terbuka pada aspek kreativitas dan kebaruan (2002: 150).

Hal tersebut seharusnya tidak dianggap sebagai membatasi peluang-peluang kreativitas, baik individu, kelompok maupun masyarakat pendukungnya. Selain dari pada itu, menurut d'Amico konsep keaslian tradisi sedikit banyaknya adalah subjektif dan tidak memiliki garis pembatas yang jelas dalam pembatas/penghambat proses kreatif. Sebuah kesenian tradisional selalu dengan berbagai alasan mengalami modifikasi, bahkan secara substansial, dengan berbagai alasan politik, ekonomi, sosial budaya dan akibat percampuran dengan budaya lainnya (2002: 30). Oleh sebab itu, setiap masyarakat memiliki cara sendiri mengekspresikan kreatifitasnya, sehingga setiap ada yang baru akan ada yang dihancurkan (proses dekonstruksi).

Asas kreatif, kebebasan, demokratisasi berekspresi, kompetisi dan indivisualisasi memacu pada terjadinya kebaruan secara terus menerus (Sachari, 2002: 149). Kreativitas yang dilakuan grup musik Kompang Delima Bantan adalah aneka cara yang dilakukan dalam menggerakan pemecahan masalah yang disadari. Melalui daya kreatifitasnya restruksisasi dan dibarengi oleh keberanian para pemainnya, sehingga terbentuk dan tercipta satu repertor pertunjukan musik Kompang baru yang kreatif. Perkembangan tersebut direncanakan dengan sistem perubahan dan perkembangan yang dilakukan anggota kelompok dengan cara evolusi kreativitas gerak dalam permainan Kompang.

Pentingnya kreativitas ini seperti dinyatakan Amir, pemain Kompang kelompok Delima, sebagai berikut.

Awalnya dilakukan perubahan dalam penyajian yang sebelumnya hanya duduk atau berdiri saja kemudian diganti dengan atraksi. Pertama, karena melihat banyak seni tradisi yang telah mengisi dengan gerak atraksi seperti musik zapin. Pernah ikut lomba tapi tidak menang. Ini adalah pengalaman buruk dengan hanya menampilkan kemonotonan pertunjukan. Kemudian kami rapat dan mulai memikirkan kreativitas gerakan-gerakan pada permainan Kompang. Hasilnya, dengan melakukan perubahan yang dilakukan dari hari ke hari Grup Delima mulai memiliki satu pola gerak yang konsisten dan memiliki kekhasan (Wawancara Amir, 5 November 2016 di Bengkalis, Riau). 
Menurut Devung, konteks lain yang memungkinkan berperannya seni pertunjukan tradisional adalah adanya berbagai peristiwa, seperti kedatangan pejabat pemerintah atau festival seni daerah yang dijadikan sebagai kesempatan dalam menampilkan seni pertunjukan tradisional dengan maksud sebagai hiburan, rekreasi, dan penilaian artistik (1997: 40).

Karakter kreativitas ada pada setiap orang yang menyukai perubahan, pembaharuan, kemajuan dan tantangan, apapun profesinya. Dengan demikian, kreativitas melahirkan nilai-nilai yang membentuk karakter dan perilaku seseorang yang selalu kreatif, berdaya, bercipta, berkarya, dan berusaha dalam rangka meningkatkan cita rasa estetik maupun daya jualnya. Menurut Barron, kreativitas didefenisikan sebagai kemampuan untuk menciptakan sesuatu yang baru (Ngalimun, dkk, 2013: 44). Kreativitas membutuhkan kesadaran akan wawasan budaya yang bertujuan memperkokoh dan memperkaya identitas kebudayaan, memperluas peran serta masyarakat dalam kegiatan kebudayaan, dan memajukan industri kebudayaan. Dalam karya seni, seperti dikemukakan Ratna, aktivitas kreatif itu seniman menciptakan karya, dengan harapan agar karya yang dihasilkan disambut oleh masyarakat luas (2012: 300). Jika karya seni tidak ada respon dan sambutan dari masyarakatnya, maka seniman akan merasa kecewa karena seni tidak berfungsi dalam kehidupan sosial.

\section{Presentasi Kompang sebagai Kesenian Etnik dan Kesenian Rakyat}

Keragaman kesenian etnik Melayu Riau, khususnya masyarakat Bantan Tua, memiliki musik, tari, puisi, pantun, sastra rakyat, tradisi bercerita, dan lainnya. Warisan budaya ini ada yang mengalami keterpinggiran, ada yang "terengah-engah" untuk tetap dapat hidup, dan ada juga yang masih tetap hidup di tengah banyaknya pilihan dari kesenian popular lainnya. Dalam hal ini, permasalahan difokuskan pada masalah potensi dan peluang kesenian etnik yang tetap dapat menunjukkan eksistensinya. Kesenian Kompang menjadi salah satu kesenian etnik yang dapat hidup berkembang didukung oleh masyarakatnya. Kehidupan kesenian tersebut sebagai kesenian rakyat terlihat pada eksistensi kesenian tersebut dalam kehidupan sosial masyarakat Bantan Tua, Bengkalis. Penampilan kesenian Kompang hampir dipertunjukkan pada semua kegiatan masyarakat maupun pemerintah.

Musik Kompang adalah permainan alat musik yang diiringi dengan nyanyian dan syair lagu-lagu bernafaskan Islam. Syair bersumber dari kitab Barzanji. Permainan musik Kompang memiliki perbedaan dengan musik Islam lainnya, yakni pada motif ritme lagu yang begitu banyak, variasi pukulan, dan teknik permainan. Keunikan lain, banyaknya kelompok-kelompok musik Kompang di Bengkalis dengan varian dari sistem pertunjukannya yang berbeda-beda.

PertunjukanKompangmerupakan penggabungan antara nyanyian vokal berisikan puji-pujian kepada Allah SWT dan Rasulullah SAW dengan bunyi-bunyian dari alat musik yang disebut Kompang, dan popular pada masyarakat Melayu, khususnya di Bengkalis yang memiliki pernyataan, "di mana ada orang Melayu, di situ ada Kompang." Seni pertunjukan bertujuan mempertunjukkan atau menyajikan sebuah karya seni kepada masyarakat (Sumandyo, 2012: 1-2). Di Bengkalis, hidup dan berkembang seni pertunjukan yang bernafaskan Islam, yakni pertunjukan Kompang. Menurut Morris, strategi ini merupakan cita-cita semua kelompok etnis yang ingin memiliki status yang setara dan hak untuk melestarikan warisan-warisan budayanya masingmasing (Barker, 2005: 480).

Kesenian Kompang sebagai seni yang bernafaskan Islam, dapat ditemui di setiap perayaan hari-hari besar Islam, seperti mau- 
lid Nabi Muhammad SAW, Hari Raya Idul Fitri, penyambutan Ramadhan, khatam Al Qur'an, akikah, khitanan, dan perayaan 1 Muharram. Di samping itu, pertunjukan Kompang juga dapat disaksikan dalam upacara adat perkawinan, yakni pada arakarakan pengantin dan acara tepuk tepung tawar, penyambutan tamu terhormat, dan sebagainya (Minawati dan Nursyirwan, 2016: 162).

Pertunjukan kesenian Kompang sebagai kesenian rakyat diklasifikasikan ke dalam bentuk hiburan, keagamaan, festival, sosial dan politik. Dalam bentuk hiburan, misalnya pertunjukan pada acara- acara yang berfungsi sebagai penyemarak dan pengembira. Sementara itu, dalam ritual keagamaan, kesenian itu menjadi media penggambaran ekspresi kereligiusan masyarakatnya, seperti terlihat pada lantunan pengajian yang berisi pujian dan rasa syukur. Kesenian Kompang sebagai salah satu pewarisan budaya kepada anak-anak melalui permainan Kompang yang disertai lantunan syair-syair Barzanji. Menurut Suryatna, musik religius tidak berarti musik menjadi agama, tetapi musik menjadi media mendekatkan diri pada Yang Maha Kuasa (2003: 142). Kegiatan diprakarsai oleh penyelenggara tertentu, yakni pemerintah kota, kabupaten, bahkan provinsi. Kegiatan tersebut tidak jarang melekat pada kegiatan program rutin pemerintah melalui Dinas Pariwisata.

Rangsangan dari kegiatan tersebut cukup berhasil memotivasi masyarakat untuk berpartisipasi dalam pertunjukan. Dampak dari kegiatan tersebut menjadikan Kabupaten Bengkalis sebagai pemilik kelompok Kompang yang paling banyak dibanding daerah-daerah wilayah Melayu lainnya. Hal tersebut dibuktikan dengan diadakannya festival 1000 (seribu) Kompang setiap tahun. Kegiatan tersebut diikuti oleh kelompok-kelompok Kompang dengan sangat antusias. Sementara itu, yang berhubungan dengan aspek sosial adalah hal-hal yang memiliki keterkaitan dengan praktik-praktik peristiwa budaya masyarakat Bengkalis yang melibatkan pertunjukan Kompang sebagai satu bagian yang penting di dalamnya.

Secara sosial, pertunjukan Kompang menjadi satu perekat dalam intraksi sosial masyarkat Bantan, Bengkalis. Kesenian Kompang juga menjadi bagian dari politik identitas masyarakat Bantan, Bengkalis. Hal tersebut terlihat dari adanya kelompok seni Kompang di setiap kampung, bahkan lebih dari satu kelompok di setiap desa. Saking pentingnya keberadaan Kompang sebagai identitas sebuah desa, masyarakat beranggapan bahwa desa yang tidak memiliki grup kesenian Kompang akan dipandang sebelah mata. Artinya, kesenian Kompang menjadi simbol prestisius antara satu kelompok masyarakat dengan kelompok masyarakat lainnya. Dalam konteks ini, kesenian Kompang menjadi media penyampai ekspresi politik identitas masyarakat Bantan Tua, Bengkalis. Hal ini menunjukkan begitu populernya pertunjukan kesenian Kompang di tengah-tengah masyarakatnya. Kelompok-kelompok Kompang juga memiliki ruang berkompetisi antara satu kelompok dengan kelompok lain, dan dari daerah satu dengan daerah lainnya. Beberapa kelompok Kompang juga berhasil menjadikan Kompang menjadi popular kembali di tengah masyarakat luas.

Kadangkala fungsi-fungsi yang telah diklasifikasikan di atas juga tumpang tindih dan saling berhubungan dalam praktik pertunjukannya. Maksudnya, dalam konteks tertentu kesenian Kompang sekaligus sebagai hiburan, sosial, keagamaan, dan politik. Dari sudut lainnya, dapat dicermati bahwa kesenian Kompang berfungsi untuk pendidikan dan pengajaran. Suryatna dalam tulisannya berjudul "Ully Hary Rusady: Memadukan Alam, Musik, dan Tradisi" menyatakan bahwa musik bagi Ully tidak sekedar hiburan, musik juga adalah religius, pendidikan dan pengetahuan, ser- 
ta terapi (2003: 141). Hal ini terlihat pada masyarakat Bantan, Bengkalis. Fungsi keagamaan dalam kesenian itu menggambarkan kereligiusan masyarakatnya, di samping berfungsi sebagai hiburan. Konsep pertunjukan kesenian Kompang menggabungkan unsur-unsur sastra, tari (formasi gerak), musik, dan teaterikal. Hingga kini, banyak perubahan berbentuk kreativitas yang dilakukan masyarakat dalam meremajakan pertunjukan kesenian Kompang. Pada perubahan-perubahan tersebut belum pernah ada kelompok yang menyanyikan lagu daerah atau pop dalam materi lagunya. Hal tersebut dikarenakan kesenian Kompang identik dengan lantunan syair yang bersumber dari kitab Barzanji.

Permainan kesenian Kompang terdiri atas 12 (dua belas) bagian, yakni: pukulan mabon, ngendong, pecah limo, nyarang, nginan, tratat, pecah rapat, nginan nyarang, mecah nginan, selang ngendong, selang pecah rapat, dan jidor. Permainan pola-pola pukulan dan vokabuler vokal dipengaruhi oleh keberadaan makharijul huruf (cara/tempat pengucapan huruf Arab). Makharijal huruf tidak hanya hadir dalam konteks pembacaan huruf hijaiah, akan tetapi mengikat permainan pola-pola pukulan Kompang yang juga mempengaruhi tingkat pemaknaan para pemain terhadap makna teks lagu. Di Bengkalis, tidak seluruh kelompok musik Kompang masih mempertahankan makharijal huruf sebagai bagian terpenting dalam permainan musik Kompang. Hal tersebut ditemui pada kelompok musik Kompang anak-anak, remaja laki-laki, dan remaja wanita. Makharijal huruf ditempatkan sebagai konsep keindahan permainan musik Kompang (Minawati dan Nursyirwan, 2016: 81).

Penyelenggaraan pertunjukan kesenian Kompang bukan hanya oleh pemerintah, swasta, masyarakat (individu). Penyelenggaraan yang bersifat individu dikategorikan sebagai bantuan dalam bentuk kepedulian

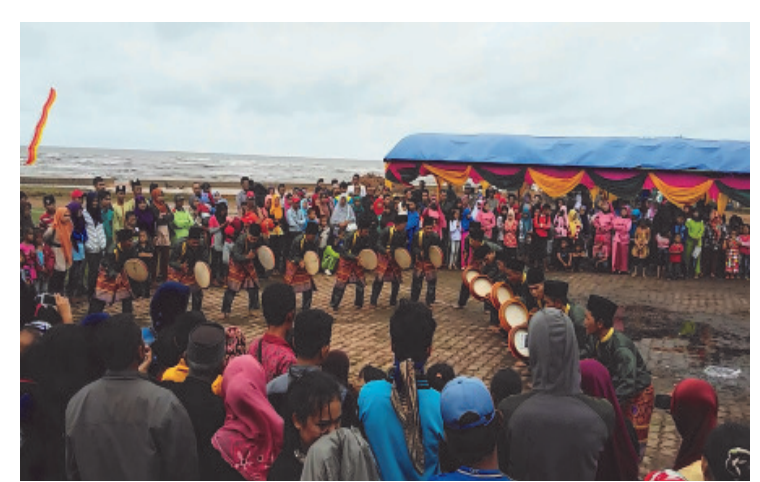

Gambar 3. Pertunjukan Kompang Grup Delima pada Pesta Pantai

Dok. Rosta Minawati dan Nursyirwan, 2016

dan perhatian masyarakat terhadap seni dan kebudayaannya. Dengan demikian, peran masyarakat menjadi penting dalam mendukung dan melestarikan kesenian etnik sebagai kesenian rakyat. Tempat-tempat pertunjukan juga bervariasi, baik panggung prosinium, halaman rumah, jalan, aula, pinggir pantai, dan lain-lain, seperti terlihat pada gambar 3.

Pada gambar tersebut telihat masyarakat begitu antusias dalam menyaksikan pertunjukan Kompang. Tempat pertunjukan tersebut menggambarkan kesenian Kompang dekat sekali dengan masyarakat pendukungnya. Panggung pertunjukan kesenian Kompang memiliki keunikan karena tidak dilengkapi dengan tata artistik, pencahayaan, atau reka bentuk pentas yang cangih. Pertunjukan Kompang dengan penataan panggung sangat sederhana, ditampilkan langsung tanpa pengeras suara dan bunyi hanya dihasilkan dari pukulan Kompang dari permainan pemain Kompang. Oleh sebab itu, terkadang syair yang dilantunkan kurang dapat didengar dengan jelas artikulasi yang dilantunkannya. Kesederhanaan lainnya, yakni pada garapan harmonisasi suara lantunan permainan Kompang.

Pelembagaan kesenian yang bersifat profesional perlu dilengkapi dengan manajemen yang ahli dalam bidang pemasaran, pelatihan, artistik, dan pengembangan. Kecintaan terhadap warisan budaya 
tersebut perlu dipupuk di dalam masyarakat modern dan generasi muda melalui pendidikan formal, sanggar, Lembaga Adat Melayu (LAM), dan tempat-tempat yang dibina oleh pemerintah (khusus pariwisata). Lembaga-lembaga ini memainkan peran penting dalam memupuk kecintaan masyarakat modern dan generasi muda dalam melestarikan kesenian etnik sebagai kesenian rakayat. Di sisi lain, munculnya berbagai kelompok dengan berbagai variasi dan kemasan menimbulkan kekhawatiran akan bergesernya fungsi dan nilai-nilai yang terkandung pada kesenian Kompang tersebut. Menurut Jazuli pada kesenian terdapat hubungan dialektik antara tradisi, inovasi, partisipasi, dan profesi. Seniman atau pelaku seni tidak dapat dilepaskan dari kehidupan kesenian Kompang. Dalam konteks ini, kehidupan seni tradisional diuraikan sebagai berikut: (1) hubungan antara seni tradisi dan inovasi memerlukan pengaturan dan manejemen, (2) hubungan dengan partisipasi membutuhkan pengayaan dan rekayasa, (3) hubungan partisipasi dengan profesi dimediasi oleh legalitas, tatanan etis, dan normatif, (4) hubungan antara tradisi dan partisipasi memerlukan subsidi, (5) hubungan antara inovasi dan profesi memerlukan sikap proaktif dan kreativitas (Jazuli, 2000: 97).

Daya tarik dalam pertunjukan terletak pada gerakan-gerakan memainkan Kompang dengan diiringi nyanyian dan pukulan-pukulan Kompang secara rampak dan teratur. Gerak tersebut merupakan salah satu bentuk kreativitas dalam melestarikan dan mengembangkan seni tradisi tanpa meninggalkan nilai-nilai ketradisiannya. Dalam kaitan ini, kelangsungan sebuah tradisi sangat bergantung dari adanya kreativitas atau inovasi yang terus menerus dari pendukungnya dalam mengembangkan keunikan perorangan, detail, kebiasaan, persepsi intern, dan ekstern (Murgiyanto, 2004: 3). Kreativitas Grup Delima terli- hat dalam menghadirkan gerakan dalam pertunjukan Kompang, yakni gerak silat, tukar kaki, nunduk, dan siku kaluang. Gerakan silat terdiri atas gerakan serang dan tangkis, gerakan tukar kaki adalah bagian dari gerakan bunga silat, dan siku kaluang adalah gerakan yang terdapat dalam gerak tari Melayu di daerah Bengkalis. Sementara itu, gerak nunduk merupakan konsep gerak inti, dan sebagai penciri gerak grup Delima Bantan Tua, Bengkalis. Gerakan tersebut merupakan stilisasi dari gerakan mengambil karet sebagai mata pencaharian masyarakat (termasuk anggota grup Delima). Dari keempat gerakan inti tersebut kemudian berkembang gerakan-gerakan lainnya yang membuat gerakan atraksi jadi lebih menarik, di antaranya adalah melempar Kompang, mengayun Kompang, dan lain sebagainya. Gerakan pukulan Kompang juga bagian dari gerakan yang atraktif, yang terkadang dipukul dengan lembut dan terkadang dipukul sangat keras.

Atraksi yang variatif itu menampilkan gerakan-gerakan di dalam kesenian Kompang oleh para pemusik yang sekaligus berperan menjadi penari dalam pertunjukan musik. Kompang dijadikan sebagai properti di dalam melakukan gerakan-gerakan yang atraktif. Meskipun demikian, ada juga pertunjukan musik Kompang yang ditampilkan tanpa ada gerakan atraksi, disesuaikan dengan acara yang berlangsung, seperti arak-arakan penganten tetap dengan arak-arakannya. Ragam gerak dalam Kompang diawali dengan salam sebagai pembuka pertunjukan yang diikuti oleh lantunan lagu asalamualaikum warahmatulahi wabarakatu. Gerakan berikutnya adalah gerakan inti, dengan menampilkan berbagai gerak yang diikuti formasi gerak yang menarik. Atraksi silat yang dilakukan pemain berjumlah dua orang. Atraksi tersebut menunjukkan adanya kreativitas pemain yang berbeda dengan kelompokkelompok lainnya. Penutup penampilan 
dengan mengatur formasi yang menarik dan diakhiri dengan pukulan Kompang yang serentak dan rampak.

Pertunjukan Kompang dimainkan dengan pola permainan interlocking. Dalam teknik interlocking, Kompang dimainkan oleh dua belas orang pemain masing-masing bertindak sebagai pemain yang memainkan motif pukulan yang diberi sebutan mabon, mecah, mecah gendong, apek mecah gendong, selang gendong, apek selang gendong, teratat satu, teratat delapan, teratat dua belas, teratat delapan belas, menginan, dan cedol (Nursyirwan, 2005: 83). Teknik interlocking sebagai ekspresi dalam permainan Kompang secara berurutan, terutama mabon, menjadi dasar pemain yang memainkan pertama kali kemudian diikuti oleh mecah dan dilanjutkan dengan penggabungan anatara mabon dan mecah.

Sistem pukulan dalam musik Kompang bermacam-macam, ada yang dikenal dengan istilah bertepuk, artinya pukul. Bermain, yang artinya ngendung atau bulat bunyinya, dan berarak yang artinya perang, atau agak mengembang bunyinya. Kemudian ada lagi yang dinamakan mecah ngendong. Artinya, kunci atau pemberi kode turun naik dalam bermain. Kompang pertama kali dipukul ada turun naik, ada pula bendung. Artinya, dalam bunyi pukulan Kompang itu kedengarannya bulat dengan posisi jari merapat, sedangkan mecah (perang) bunyi pukulannya pecah atau tidak bulat dengan posisi jari tangan terbuka atau tidak rapat (Minawati dan Nursyirwan, 2016: 83).

Motif-motif pukulan secara bersahutsahutan memancing ekspresi musikal dan memberikan motivasi kepada pemain. Sewaktu mabon dan mecah bermain, maka pemain yang ketiga mengikuti teknik pukulan mecah gendong. Demikian seterusnya terjadi pada motif pukulan apek mecah gendong, selang gendong, apek selang gendong, teratat satu, teratat delapan, teratat dua belas, teratat delapan belas, menginan, dan cedol.
Ekspresi dimunculkan dengan motif pemecah agar terjalin nada-nada kedua belas orang pemain Kompang (Minawati dan Nursyirwan, 2016: 83).

Sistem permainan musik Kompang terdiri atas kesatuan permainan pola-pola gendang bermuka satu dan vokabuler-vokabuler vokal yang menyenandungkan teks-teks kitab Barzanji. Keberadaan vokal sejalan dengan permainan pola-pola pukulan Kompang. Pola-pola pukulan mengiringi vokal dan ada kalanya polapola pukulan berdiri sendiri tanpa ada vokal. Vokal dilantunkan dengan pola tanya jawab yang lazim disebut adi. Adi adalah teks lagu berupa frasa kalimat tanya-jawab yang ditulis dengan huruf hijaiah. Teks tersebut berisi puji-pujian kepada Allah SWT, salawat Nabi, tauladan kepada Rasul dan sejarah hidupnya mulai dari Nabi lahir sampai nabi wafat (Minawati dan Nursyirwan, 2016: 80).

Di dalam pertunjukan, keberlangsungan permainan pola-pola pukulan dan vokabuler vokal dipengaruhi oleh keberadaan makharijal huruf. Makharijal huruf ditinjau dari morfologi berasal dari fi'il madhi (kata kerja bentuk lampau), yaitu kharaja yang artinya keluar, kemudian dijadikan berwazam maf'alun (yang dikenai pekerjaan) menjadi makhrajun yang berarti tempat keluarnya huruf (Minawati dan Nursyirwan, 2016: 80). Dalam bahasa Indonesia istilah makhraj setara makna yang berarti ketepatan ucapan (KBBI, 1997: 168). Masyarakat Melayu Bengkalis lazim disebut dengan makhrijal huruf yang setara artinya dengan ketepatan pengucapan huruf.

Pada prinsipnya, dalam pemahaman Islam, pengucapan huruf-huruf hijaiah sangat terikat dengan hukum-hukum bacaan yang lazim disebut tartil (bacaan yang baik/ teratur) yang diatur dalam ilmu tajwid. Dalam hal ini, terdapat beberapa prinsip dasar sebagai hukum bacaan, antara lain: pertama, izhar, yakni kejelasan mengelu- 
arkan huruf tanpa sengau atau dengung. Kedua, idgham, yakni mengucapkan dua huruf menjadi satu huruf, huruf yang kedua menjadi bertasdik. Ketiga, iqlab, yakni menjadikan suatu huruf kepada huruf lain seraya menjaga ghunnah (sengau). Keempat, ikhfa, yakni mengucapkan huruf dengan sifat izhar dan idgham tanpa 'bertasdik' dan menjaga 'ghunnah'. Kelima, qalqalah, yakni suara tambahan atau pantulan yang kuat dan jelas terjadi pada huruf yang 'bersukun', dan keenam, waqaf, yakni memutuskan suara pada suatu kalimat tertentu dalam waktu beberapa saat, kemudian mengambil nafas dan memulai kembali bacaan, serta ketujuh, mad, yakni memanjangkan suara dengan salah satu huruf dari huruf-huruf mati (Minawati dan Nursyirwan, 2016: 81).

Di dalam permainan musik Kompang, keberadaan makharijul huruf tidak hanya hadir sebatas dalam konteks pembacaan huruf hijaiah. Lebih jauh, mengikat permainan pola-pola pukulan Kompang yang juga memengaruhi tingkat pemaknaan para pemain terhadap makna teks lagu. Oleh sebab itu, keberadaan makharijul huruf dalam permainan musik Kompang sangat memberi arti terhadap keindahan permainan. Pada kenyataannya, pada masyarakat Bengkalis, tidak seluruh kelompok musik Kompang masih mempertahankan makharijul huruf sebagai bagian terpenting dalam permainan. Hal ini sebagaimana yang dinyatakan Mohamad, bahwa ruang ekspresi dari pertunjukan Kompang mencerminkan historis, budaya, komunitas, tradisional, dan modern (2000: 52).

Perkembangan kesenian Kompang di tengah masyarakat dilandasi oleh sikap kreatif dan inovasi dari pelaku seni budaya tersebut. Kesenian Kompang memiliki eksistensi dengan segala kemungkinan dinamika perubahan dalam menghadapi perkembangan zaman. Ide-ide baru men- jadi unsur utama keinginan pelaku dan pendukungnya agar kesenian Kompang tetap dapat eksis dan berdaya saing di tengah menjamurnya seni lainnya. Menurut Bahari, prinsip kreativitas dan inovasi yakni memberi nilai tambah pada suatu produk agar muncul produk baru dari yang telah ada sebelumnya (2008: 23).

\section{SIMPULAN}

Musik Kompang memiliki potensi dan kekuatan sebagai politik identitas di Bengkalis Riau, khususnya di Bantan. Kreativitas sebagai strategi pengembangan budaya lokal dalam mengaktualkan seni budaya lokal merupakan wujud dari kearifan budaya lokal masyarakat Bantan, Bengkalis. Penggarapan bentuk dan sistem penyajian pertunjukan musik Kompang dengan menampilkan ragam gerak dan formasi yang diatur sedemikan indah. Pola lantai dan konsep nunduk menjadi kekhasan pertunjukan grup Kompang Delima. Kreativitas sebagai strategi tampak pada proses dan hasil produk pertunjukan musik Kompang grup Delima Bantan Tua, Bengkalis.

\section{Daftar Pustaka}

Bahri, N. (2008). Kritik Seni. Yogyakarta: Pustaka Pelajar.

Barker, C. (2005). Cultural Studies: Teori dan Praktik. Yogyakarta: Bentang.

Barkker, J. W. M. (1984). Filsafat Kebudayaan sebuah Pengantar. Yogyakarta: Kanisius.

Bramantyo, T. (2000). Revitalisasi Musik Tradisi dan Masa Depannya. Widjajadi dan Sahid (Ed). Mencari Ruang Hidup Seni Tradisi. Yogyakarta: Fakultas Seni Pertunjukan (BP FASPER).

Brannen, J. (2005). Memandu Metode Penelitian Kualitatif dan Kuantitatif. Yogyakarta: Pustaka Pelajar.

D'Amico, L. (2002). Seni Pertunjukan Tradisional dan Globalisasi: Pilihan Etnik, Etik, dan Estetik. Seni Pertunjukan Indonesia, Th. XI. Jakarta: MSPI. 
Devung, G. S. (1997). Seni Pertunjukan Tradisional di Dataran Tinggi Mahakam: Situasi Masa Kini dan Prospek Masa Depan. Seni Pertunjukan Indonesia, Th VIII. Bandung: MSPI.

Endraswara, S. (2010). Folklore Jawa: Macam, Bentuk, dan Nilainya. Jakarta: Penaku.

Hadi, Y. S. (2012). Seni Pertunjukan dan Masyarakat Penonton. Yogyakarta: BP ISI Yogyakarta.

Alatas, S. H. (1976). Bahasa Kesusastraan dan Kebudayaan Melayu. Kuala Lumpur: Kementrian Kebudayaan, Belia dan Sukan Malaysia.

Julianto, I. N. L., dkk. (2016). “Nilai Interaksi Simbol Tradisi dalam Wujud Pelinggih pada Ruang Publik". Panggung, 26 (3), 24-34.

Kasidi, HP. (2000). Pengembangan Struktur Pergelaran Wayang Gaya Yogyakarta Masa Kini. IDEA 1 (11), 74-84.

Minawati, R. dan Nursyirwan. (2016). Musik Kompang Bengkalis Riau. Yogyakarta: Graha Cendikia.

Mohamad, Z. B. H. (2000). Istana, Pasar, Desa dan Jalanan: Politik dan Puitika Ruang dan Ekspresi. Seni Pertunjukan Indonesia Thn. X, 52.

Moleong, L. J. (1999). Metodologi Penelitian Kualitatif. Bandung: Penerbit Remaja Rosdakarya.

Murgiyanto, S. (2004). Tradisi dan Inovasi. Jakarta: Wedatama Widya Sastra.

Ngalimun, dkk. (2013). Perkembangan dan Pengembangan Kreativitas. Yogyakarta: Aswaja Pressindo.
Poespowardojo, S. (1987). Strategi Kebudayaan: Suatu Pendekatan Filosofis. Jakarta: PT Gramedia.

Raharja, B. (2000). Kerawitan Jawa dalam Konteks Musik Asia. IDEA 1 (11), 12-22.

Ratna, N. K. (2011). Antropologi Sastra: Peran Unsur Kebudayaan dalam Proses Kreatif. Yogyakarta: Pustaka Pelajar.

Ratna, N. K. (2011). Estetika Sastra dan Budaya. Yogyakarta: Pustaka Pelajar.

Ruswandi, T. 2016. Kreativitas Mang Koko dalam Karawitan Sunda. Panggung, 26, (3), 92-107.

Sachari, Agus. (2002). Estetika: Makna, Simbol dan Daya. Bandung: ITB.

Sedyawati, Edy. (2004). Penelitian Seni: Jenis dan Metodenya. Lokakarya. Yogyakarta: LPPM ISI Yogyakarta.

Soedarsono, RM. (2001). Metodologi Seni Pertunjukan dan Seni Rupa. Bandung: MSPI.

Soegoto, E. S. (2009). Entrepreneurship Menjadi Pebisnis Ulung. Jakarta: Elex Media Komputindo Kompas Gramedia.

Suryatna, Y. (2003). Ully Hary Rusady: Memadukan Alam, Musik, dan Tradisi. Seni Pertunjukan Indonesia Thn XII. Bandung: MSPI.

Widjajadi, R A. S. (2000). Menggugat Kemandirian Musik Keroncong. IDEA, 1 (11) 3-18.

Wikandia, R. (2016). Pelestarian dan Pengembangan Seni Ajak Sinar Pusaka pada Penyambutan Pengantin Khas Karawang. Panggung, 26 (3), 58-69. 